\title{
Monitoring for adaptive management in a trial reintroduction of the black-footed rock-wallaby Petrogale lateralis
}

\author{
Rebecca West, John Llemellyn Read, Matthew James Ward \\ WENDY K. FOSTER and DAVID A. TAGgarT
}

\begin{abstract}
Reintroduction practitioners must often make critical decisions about reintroduction protocols despite having little understanding of the reintroduction biology of the focal species. To enhance the available knowledge on the reintroduction biology of the warru, or black-footed rock-wallaby Petrogale lateralis MacDonnell Ranges race, we conducted a trial reintroduction of 16 captive individuals into a fenced predator and competitor exclosure on the Anangu Pitjantjatjara Yankunytjatjara Lands in South Australia. We conducted seven trapping sessions and used radio-tracking and camera traps to monitor survival, reproduction and recruitment to the population over 36 months. Blood samples were collected pre-release and during two trapping sessions post-release to assess nutritional health. The survival rate of founders was $63 \%$, with all losses occurring within 10 weeks of release. Post-release blood biochemistry indicated that surviving warru adapted to their new environment and food sources. Female warru conceived within 6 months of release; 28 births were recorded during the study period and $52 \%$ of births successfully recruited to the population. Our results suggest that captive-bred warru are capable of establishing and persisting in the absence of introduced predators. However, the high mortality rate immediately post-release, with only a modest recruitment rate, suggests that future releases into areas where predators and competitors are present should use a trial approach to determine the viability of reintroduction. We recommend that future releases of warru into unfenced areas include an intensive monitoring period in the first 3 months post-release followed by a comprehensive long-term monitoring schedule to facilitate effective adaptive management.
\end{abstract}

REBECCA WeST (Corresponding author) The University of New South Wales c/o Arid Recovery, PO Box 147, Adelaide, SA 5725, Australia, and School of Biological Sciences, The University of Adelaide, Adelaide, SA 5005, Australia E-mail rebecca.west@unsw.edu.au

John Llewellyn Read Ecological Horizons, Kimba, South Australia

MatThew James Ward Department of Environment, Water and Natural Resources, Natural Resources Alinytjara Wilurara, Adelaide, South Australia

Wendy K. Foster Royal Zoological Society of South Australia, Frome Road, Adelaide, South Australia

DAvid A. TAGGart Fauna Research Alliance Ltd, Callaghan, New South Wales, Australia

Received 31 October 2015. Revision requested 2 December 2015.

Accepted 23 December 2015. First published online 5 April 2016.
Keywords Adaptive management, Australia, Petrogale, rock-wallaby, species monitoring, trial reintroduction, warru

\section{Introduction}

eintroduction is defined as the intentional release of an Rorganism into part of its native range from which it has become extinct (IUCN, 2013). Determining the optimum reintroduction protocol for a species is one of the biggest challenges for reintroduction practitioners, and therefore we are encouraged to incorporate well-designed experiments into releases to determine these parameters (Armstrong \& Seddon, 2008). True experiments are not always possible however, especially for threatened species, of which only a small number of individuals may be available for release (Sheean et al., 2012). Nonetheless, trial reintroductions (uncontrolled and unreplicated releases) can be useful tools to test the likelihood of establishment at a particular site and to provide critical preliminary data where no previous knowledge exists (Kemp et al., 2015).

Reintroduction was determined to be a key conservation tool for the black-footed rock-wallaby Petrogale lateralis MacDonnell Ranges race in South Australia (Read \& Ward, 2011a), where the species is categorized as Endangered (Woinarski et al., 2014). This chromosomal race of $P$. lateralis was once widespread across the central ranges of Western Australia, the southern Northern Territory and northern South Australia (Pearson, 2012). However, there has been a 93\% contraction in the distribution of the species in South Australia, with c. 250 individuals remaining in the north-west of the state on the Anangu Pitjantjatjara Yankunytjatjara Lands (Ward et al., 2011b). The species is known to traditional owners of the Lands as warru. Predation by the introduced feral cat Felis catus and red fox Vulpes vulpes is thought to be the major cause of decline and remains a significant threat to the species (Read \& Ward, 2011a).

Given the low number of wild individuals, wild-to-wild reintroductions were not pursued. Instead joeys were collected from the three remaining wild populations (New Well, Alalka and Kalka) during 2007-2009 and cross-fostered (Taggart et al., 2010) to yellow-footed rock-wallaby Petrogale xanthopus surrogate mothers at Monarto Zoo, South Australia. Once they became independent the warru were housed in 
an off-limits area (away from public access) in low scrub enclosures, with shelves and logs providing vertical height, and cement pipes for hides. Captive warru were fed on kangaroo pellets, lucerne hay, water ad libitum and browse (lucerne tree Cytisus proliferus and willow Salix sp.). Males were housed separately because of aggressive behaviours and females were housed in groups of two or three. No predator training occurred while the warru were held in captivity. During 2009-2011 a number of individuals were housed in breeding groups, resulting in a captive population of 26 by 2011.

Despite reintroduction being recommended for warru, knowledge of the reintroduction biology of the species was sparse (Read \& Ward, 2011a). A number of previous wild-to-wild translocations had been successful (Pearson, 2012) but reintroductions using captive-bred individuals had not been conducted. Reintroductions of captive-bred yellowfooted rock-wallabies into predator controlled areas had been successful (Lapidge, 2001) but releases of captive-bred brushtailed rock-wallabies Petrogale penicillata into predator baited areas in Victoria failed to establish self-sustaining populations because of predation by foxes, disruption to the social structure of the colony and slow onset of reproduction (Weeks, 2012). As predation by introduced predators has been the most significant cause of reintroduction failures in Australia (Short, 2009; Moseby et al., 2011; Clayton et al., 2014) and optimal reintroduction protocols are known to be species and site specific (Moseby et al., 2014) the recovery team selected a two-stage reintroduction protocol. The first phase was a trial reintroduction of captive individuals into a fenced area of natural habitat, free from introduced predators and competitors. Pending the successful outcome of phase one, phase two would use individuals from the fenced area as the source population for releases to unfenced predator controlled sites.

We aimed to test whether it was feasible to establish a reintroduced population of warru using captive individuals, and the suitability of the selected habitat, and to identify adaptive management requirements for future reintroductions.

\section{Study area}

A 97 ha predator exclosure was constructed at Donald's Well (Fig. 1), c. $17 \mathrm{~km}$ from the New Well colony. The fence design consisted of a floppy overhang designed to keep predators out but facilitate emigration of climbing animals such as warru (Moseby \& Read, 2006; for full details of site selection and fence specifications see Muhic et al., 2012). The exclosure contained two areas, which could be separated if needed. The larger paddock surrounded a granite outcrop with multi-entrance caves, deep fissures and an abundance of key food plants for warru, namely fig Ficus brachypoda and spearbush Pandorea doratoxylon (Fig. 1). An outlying rocky outcrop in the north-east corner of the

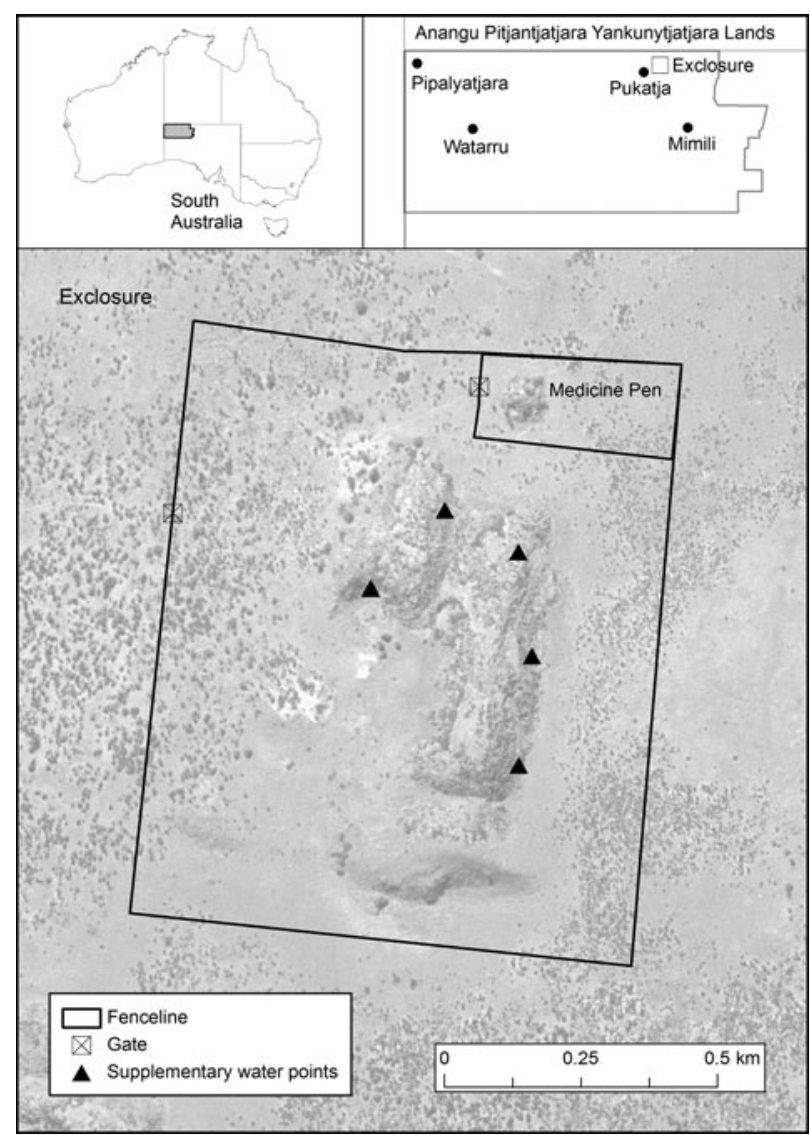

FIG. 1 Location of the 97 ha predator exclosure on the Anangu Pitjantjatjara Yankunytjatjara Lands in South Australia, into which captive-bred warru (black-footed rock-wallabies Petrogale lateralis MacDonnell Ranges race) were reintroduced.

exclosure was fenced separately for use as a medicine pen (c. 6 ha), where sick or injured animals could be placed to recover. Introduced predators were removed and attempts were made to remove euros Macropus robustus and European rabbits Oryctolagus cuniculus, which are competitors of the warru (Geelen, 1999). We estimated that three adult euros and $<10$ rabbits still remained at the first release in March 2011 but these were all removed by September 2012. No incursions of introduced predators or competitors occurred after this time.

\section{Methods}

\section{Release protocol and group composition}

A total of 16 captive warru ( 8 male, 8 female) were released in three groups between March 2011 and July 2012 (Table 1). The first release group comprised only captive-born individuals, to reduce the risk of losing captive founder genetics. Subsequent releases used a mixture of captive-bred and cross-fostered animals. 
TABLE 1 Name, sex and origin of warru (black-footed rock-wallaby Petrogale lateralis MacDonnell Ranges race) released into a 97 ha predator exclosure on the Anangu Pitjantjatjara Yankunytjatjara Lands in South Australia (Fig. 1), their age and weight at the time of reintroduction, and their survival status.

\begin{tabular}{|c|c|c|c|c|c|}
\hline Name & Sex & Origin & Age (days) & Weight (kg) & Survived \\
\hline \multicolumn{6}{|c|}{ Reintroduced 29 March 2011} \\
\hline Marura & Male & Captive-bred & 455 & 2.9 & Yes \\
\hline Itunpa & Male & Captive-bred & 704 & 3.6 & Yes \\
\hline Itatura & Male & Captive-bred & 643 & 2.6 & Yes \\
\hline Ngangarla & Female & Captive-bred & 530 & 2 & Yes \\
\hline Tjalpu Tjalpu & Female & Captive-bred & 592 & 2.3 & No \\
\hline \multicolumn{6}{|c|}{ Reintroduced 25 July 2011} \\
\hline Ula & Male & Cross-fostered & 1,668 & 4.7 & Yes \\
\hline Kalinya & Female & Cross-fostered & 1,308 & 3.6 & Yes \\
\hline Aliyan & Female & Cross-fostered & 1,586 & 2.6 & Yes \\
\hline Minnie & Female & Cross-fostered & 1,582 & 3.5 & Yes \\
\hline Mingkiri & Male & Cross-fostered & 1,592 & 3.7 & No \\
\hline Kupinya & Male & Cross-fostered & 1,271 & 4 & No \\
\hline \multicolumn{6}{|c|}{ Reintroduced 16 July 2012} \\
\hline Tiltin & Female & Cross-fostered & 1,834 & 3.7 & No \\
\hline Sandy & Female & Cross-fostered & 1,835 & 3.7 & Yes \\
\hline Kaanka & Female & Captive-bred & 399 & 1.5 & No \\
\hline Nyi Nyi & Male & Cross-fostered & 1,825 & 5 & Yes \\
\hline Puti & Male & Cross-fostered & 1,534 & 3.9 & No \\
\hline
\end{tabular}

In the week before each release all warru were examined by the zoo veterinarian, had a blood sample taken and were fitted with either a $96 \mathrm{~g}$ global positioning system or a $45 \mathrm{~g}$ VHF radio collar (Sirtrack Ltd, Havelock North, New Zealand), depending on their mass (maximum $3 \%$ body mass). All individuals were microchipped (Trovan Ltd, UK). Unique combinations of bands of black and white heat-shrink tubing were fitted to collar antennae to facilitate individual identification via infrared camera traps.

Supplementary water was provided in five 8-1 chicken water feeders, which were monitored by remote camera traps (Scout Guard KG68oV, Faunatech, Mount Taylor, Australia). As the granite outcrop was expected to be the primary habitat for warru, water points were placed in caves and spaced evenly across the hill (Fig. 1) to avoid biasing habitat selection and/or increasing competition between individuals. Supplementary food was not provided.

On the morning of the release warru were captured from their zoo pens and given an intramuscular injection of vitamin $\mathrm{E}$ at $0.02 \mathrm{ml} \mathrm{kg}^{-1}$ to reduce oxidative stress and minimize any risk of capture myopathy (Vogelnest \& Woods, 2008). They were placed into individual pet packs lined with straw, driven to the airport (c. 1 hour) and flown to the release site (c. 5 hours). Individuals from the first and second release groups were released into the main exclosure at dusk, at the base of the hill. In the third release group, four of the five individuals were released into the main section, with the fifth (a male) released temporarily into the medicine pen to test whether this pen could effectively separate individuals from the main exclosure.

\section{Monitoring post-release}

Three methods (radio-tracking, cage trapping and camera trapping) were used to assess (a) the survival of reintroduced warru, (b) their nutritional health post-release, and (c) reproduction and recruitment within the population.

Individuals were radio-tracked daily for the first 2 weeks post-release, then subsequently at weekly intervals throughout the study period. Radio-tracking was conducted by Anangu Warru Rangers (Muhic et al., 2012), traditional owners of the study site, whose involvement with the project was welcomed, and integral to securing permissions and funding for the translocation (Read \& Ward, 2011b). The VHF signal for the radio collars was programmed to latch into a mortality mode, indicated by a doubling in pulse rate of the signal, if no movement was detected for 12 hours.

Warru were trapped on seven occasions, in July 2011, February, May and October 2012, March and October 2013, and March 2014, using Thomas traps (Sheffield Wire Products, Perth, Australia). Traps were set throughout the creviced or boulder pile areas where warru scat was concentrated. They were baited with peanut-butter-oat balls and chopped apples, set for a maximum of 4 nights and cleared each day at dawn.

At the first capture in each session, warru were administered with an intramuscular injection of vitamin E. New 
individuals were marked with a microchip, sampled via an ear biopsy for genetic analysis and fitted with an ear-tag. Morphometric measurements were recorded for all individuals. If pouch young were present their head-length and sex were recorded. Fully furred pouch young were microchipped and an ear biopsy taken. In October 2012 and March 2013 a $1 \mathrm{ml}$ blood sample was taken from the lateral tail vein of all individuals released from captivity. Samples were placed into $1 \mathrm{ml}$ EDTA (ethylenediamine tetraacetic acid) tubes and centrifuged in the field, and the resultant plasma was separated and frozen for biochemical analyses.

Images from the five camera traps were downloaded quarterly and the photographs examined to identify individual warru at each water point, using the unique radio antenna identifiers. Thus a 'last seen on camera' date could be logged for individuals who were not detected via radiotracking or later trapped. The photographs were also used to record the condition of warru and the reproductive status of females (presence of bulging pouches or young-at-foot).

\section{Statistical methods}

A Kaplan-Meier survival analysis (Kaplan \& Meier, 1958; Pollock et al., 1989) was conducted using SPSS Statistics v. 19 (IBM, Armonk, USA) to determine the overall survival curve of warru in each release group. Separate logistic regressions were used to examine the influence of both age and weight at release on survival.

Roche Diagnostics kits and a Cobas Bio analyser (Roche Diagnostics, Risch-Rotkreuz, Switzerland) were used to perform 11 chemistry and antioxidant assays of the blood samples for ascorbic acid (vitamin C), retinol (vitamin A), alpha-tocopherol (vitamin E), total protein, albumin, urea, cholinesterase (ChE), FRAP (ferric reducing ability of plasma), TBARS (thiobarbituric acid reducing substances) and TEAC (trolox equivalent antioxidant capacity). An oxidative stress index was then calculated as the ratio of TBARS to the sum of TEAC and FRAP to represent the antioxidant capacity (TEAC + FRAP) to mitigate cell membrane damage (TBARS) (Schultz et al., 2011). The oxidative stress index was used as an indicator of how released individuals were coping with stress.

Biochemical parameters were analysed in three groups. As diet and water availability do not fluctuate seasonally in captivity, samples taken during zoo health checks were examined as one group: pre-release. Post-release samples were divided into two groups to examine seasonal variation: post-release spring (October 2012) and post-release autumn (March 2013). Mean values $( \pm S D)$ were calculated for each group and compared to wild reference values (Ruykys et al., 2012). Linear mixed-effects models were fitted using $R$ v. 3.o.2 (R Development Core Team, 2013) and the packages lme4 (Bates et al., 2013) and languageR (Baayen, 2011) to examine differences between pre- and post-release values for ascorbic acid, albumin, urea, cholinesterase, FRAP and oxidative stress index. These values have been used previously to indicate nutritional health in rock-wallaby species (Schultz et al., 2011; Ruykys et al., 2012). Retinol and alpha-tocopherol were not modelled because of the limited pre-release sample size $(n=2)$, and total protein was excluded because of a significant correlation with albumin (SPSS Pearson correlation $r=0.645$, $\mathrm{n}=34, \mathrm{P} \leq 0.001$ ). Linear mixed models (lmer) were fitted for each biochemical variable, with SEASON (pre- or postrelease spring, or post-release autumn) and SEX as fixed effects, a SEX ${ }^{*}$ SEASON interaction and a random effect of ID to account for repeated measurements on the same individuals. Residual plots for each fitted model were examined for normality. The lmer model determines the significance of each fixed effect using Markov chain Monte Carlo simulations of the posterior distribution of each parameter. The $\mathrm{P}$ values of these simulations were evaluated using pvals.fnc() in languageR (Baayen et al., 2008; Baayen, 2011). The SEX ${ }^{\star}$ SEASON interaction term was removed from the fitted models if not found to be a significant explanatory effect on a biochemical variable. Where SEASON was identified as a significant effect variable, post-hoc Tukey's all pair comparison tests were implemented using the $R$ package multcomp (Hothorn et al., 2008).

The percentage of females breeding at each trapping session was recorded. Head-length measurements were used to estimate the age (in days) of pouch young, using the revised exponential equation (Delaney \& De'ath, 1990, as outlined in Ruykys, 2011):

$$
\text { Age }=\frac{\ln (1-\mathrm{HL} / 111.88)}{-0.0051}-9.24
$$

Age (in days) was then deducted from the trapping date to estimate the date of birth. If a female had an elongated, lactating teat it was presumed that she was nursing a young-at-foot and thus we recorded a birth for that female. Pouch exit occurs at a mean of 176 days in wild warru (Ruykys, 2011) and thus to estimate the month of birth for these unsighted young 176 days was subtracted from the mother's trapping date. For untrapped female warru, camera trap photographs were analysed for pouch bulging or presence of a young-at-foot but this information did not yield accurate age estimates for young. The birth dates of pouch young were used to calculate the number of months post-release before each female was reproductive, and a birthing schedule across the year. The sex ratio of pouch young was also calculated.

Survival of pouch young to pouch exit was determined in one of three ways: (1) the presence of an elongated lactating teat on the female in the next trapping session, (2) the presence of a young-at-foot with that female at a camera trap, or (3) capture of the microchipped young as an independent individual in subsequent sessions. Mortality of individual 
pouch young was recorded if the head-length of the pouch young that a female was carrying in the next trapping session was inconsistent with the time required for the previously recorded pouch young to have been weaned, or if the female showed no sign of a bulging pouch in camera trap photographs. Recruitment of pouch young to the population was confirmed when individuals were cage-trapped independently.

\section{Results}

\section{Survival}

Of the 16 captive warru reintroduced, 10 were known to be alive in March 2014, thus $63 \%$ of founding individuals had survived and established at the release site. Corpses were retrieved for five of the founding individuals but none were recovered within a suitable time for post-mortem examination. Mortalities included one individual from the first release, one from the second and three from the third, one of which was the male that was released into the medicine pen. Camera trap images revealed loss of rump fur (indicative of fighting) and poor condition in two of these warru (one male, one female) just prior to death. The sixth, a male from the second release, was only heard via radio-tracking for 31 days post-release. A mortality signal was not detected through radio-tracking and this male was never recorded during camera or cage trapping. As this individual did not establish within the release site, for the purposes of survival analysis it was considered a loss from the population.

All deaths/losses occurred within 10 weeks of release for each group, as indicated by the Kaplan-Meier survival curve (Fig. 2), which indicates a consistent survival rate of reintroduced individuals after week 10 until the termination of the study at week 156 (group 1), 139 (group 2) and 88 (group 3). Kaplan-Meier survival analysis estimated a mean survival time of 99.1 weeks (95\% CI 63.1-135.1). Cumulative survival decreased with each release group, with $80 \%$ for group 1 , $66.7 \%$ for group 2 and $40 \%$ for group 3 (Fig. 2). Survival was not sex biased ( 6 mortalities; 3 male, 3 female). Age at release did not predict survival (odds ratio $=1.031,95 \% \mathrm{CI}$ 0.512-2.074, $\mathrm{P}=0.932$ ), nor did weight at release (odds ratio $=1.327,95 \% \mathrm{CI} 0.434-4.061, \mathrm{P}=0.62$ ).

\section{Nutritional health}

Pre- and post-release biochemical blood values are in Table 2. No significant SEASON ${ }^{\star}$ SEX interaction was found for any of the biochemical parameters and thus it was removed as a fixed effect from the linear mixed models. The final model fitted to each biochemical parameter was therefore SEASON (pre-release, spring 2012 and autumn 2013) and SEX as fixed effects, with a random effect of ID.

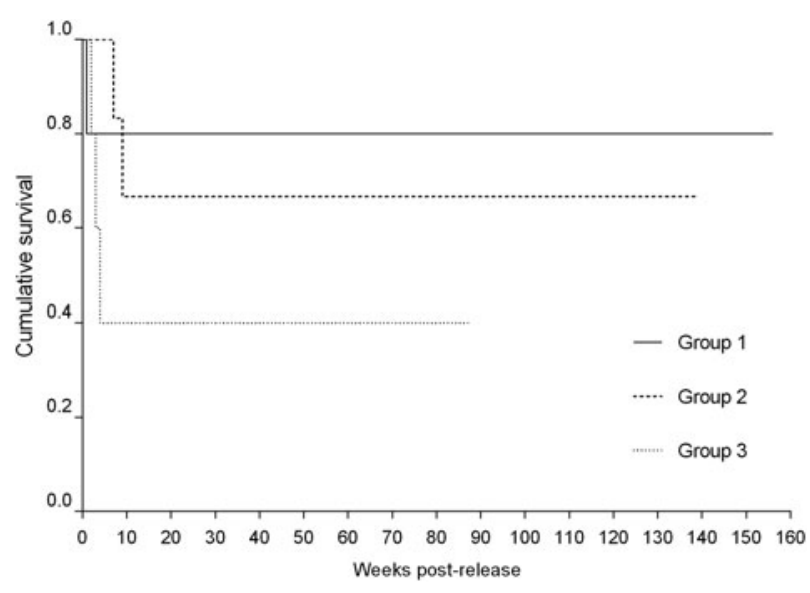

FIG. 2 The Kaplan-Meier survival curve for captive warru following soft reintroduction in three release groups (group 1, $\mathrm{n}=5$, released March 2011; group 2, $\mathrm{n}=6$, released July 2011; group 3, $\mathrm{n}=5$, released July 2012).

Residual plots for each model displayed normality. SEX did not have a significant explanatory effect on any of the biochemical variables. There was no significant effect of SEASON on ascorbic acid or FRAP values but it significantly explained variation in albumin, urea, cholinesterase and oxidative stress index values and thus Tukey's post-hoc multiple comparison tests were implemented for these four parameters (Table 2). Albumin and urea values were significantly higher pre-release than post-release but there was no difference between the spring and autumn values (Table 2). Cholinesterase and oxidative stress index values were significantly higher pre-release than in the first sampling session in spring but showed no significant difference to pre-release values in the subsequent autumn sampling period (Table 2). However, there were significant differences in both cholinesterase and oxidative stress indexes between the spring and autumn sampling periods (Table 2).

\section{Reproduction and recruitment}

All females that survived beyond 10 weeks gave birth within 2-6 months of reintroduction. In addition, four females born within the exclosure bred in their first year. A total of 28 births from nine females were recorded, with 24 of these births from five of the captive-released individuals. Births occurred in each month of the year. The sex ratio of pouch young was 15:12 male: female, with one of unknown sex (the birth was identified from an elongated lactating teat).

Excluding the pouch young from the final trapping session (which were too young to have exited from the pouch, $\mathrm{n}=6$ ) and one that died as a result of the death of its mother during trapping, survival of pouch young to permanent pouch exit was $91 \%$ (19 of 21 births). The two pouch young deaths were confirmed as the mother was not photographed with a bulging pouch after trapping, and in one case 

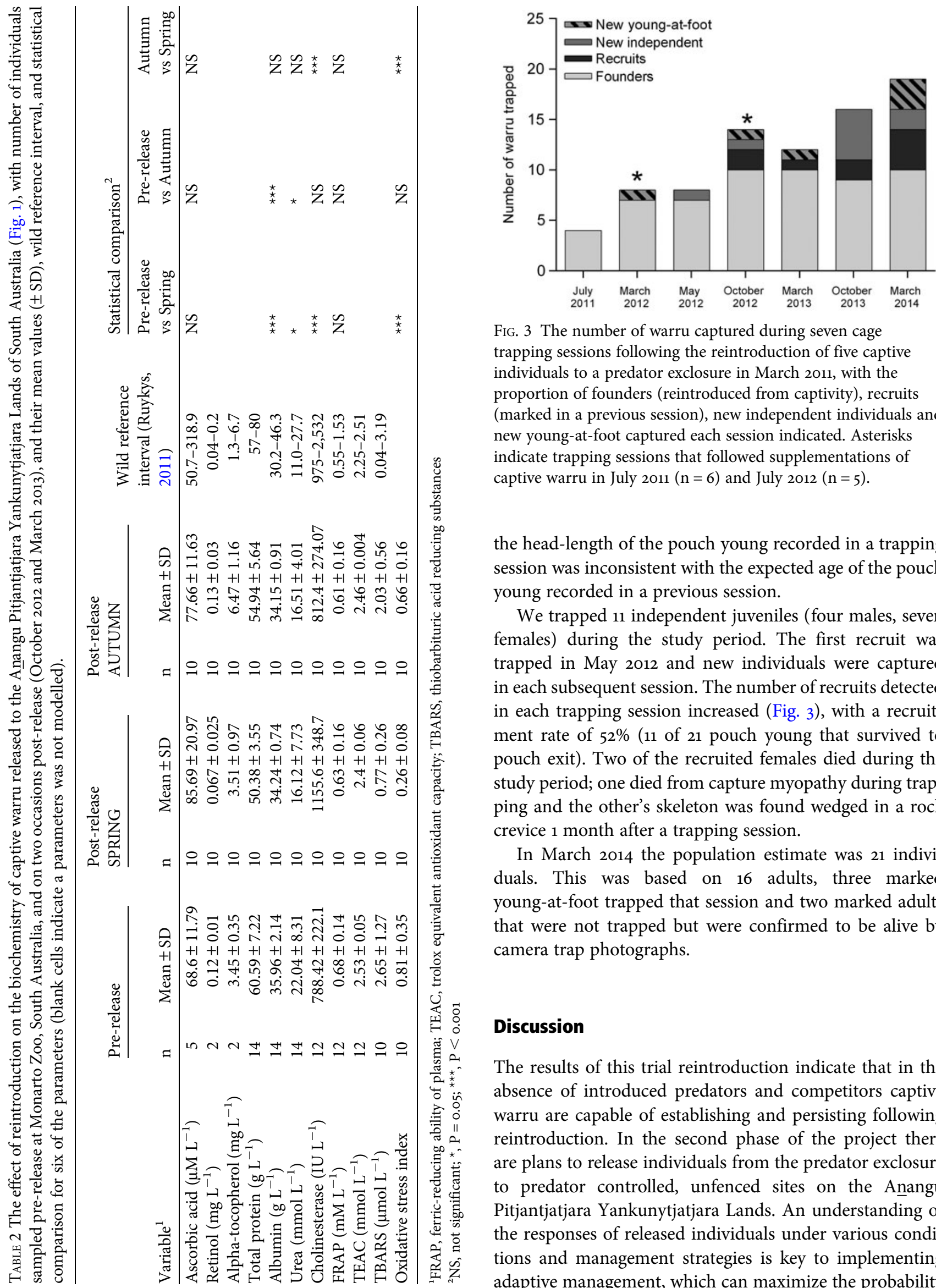

Fig. 3 The number of warru captured during seven cage trapping sessions following the reintroduction of five captive individuals to a predator exclosure in March 2011, with the proportion of founders (reintroduced from captivity), recruits (marked in a previous session), new independent individuals and new young-at-foot captured each session indicated. Asterisks indicate trapping sessions that followed supplementations of captive warru in July $2011(\mathrm{n}=6)$ and July $2012(\mathrm{n}=5)$.

the head-length of the pouch young recorded in a trapping session was inconsistent with the expected age of the pouch young recorded in a previous session.

We trapped 11 independent juveniles (four males, seven females) during the study period. The first recruit was trapped in May 2012 and new individuals were captured in each subsequent session. The number of recruits detected in each trapping session increased (Fig. 3), with a recruitment rate of $52 \%$ (11 of 21 pouch young that survived to pouch exit). Two of the recruited females died during the study period; one died from capture myopathy during trapping and the other's skeleton was found wedged in a rock crevice 1 month after a trapping session.

In March 2014 the population estimate was 21 individuals. This was based on 16 adults, three marked young-at-foot trapped that session and two marked adults that were not trapped but were confirmed to be alive by camera trap photographs.

\section{Discussion}

The results of this trial reintroduction indicate that in the absence of introduced predators and competitors captive warru are capable of establishing and persisting following reintroduction. In the second phase of the project there are plans to release individuals from the predator exclosure to predator controlled, unfenced sites on the Anangu Pitjantjatjara Yankunytjatjara Lands. An understanding of the responses of released individuals under various conditions and management strategies is key to implementing adaptive management, which can maximize the probability 
of reintroduction success (Armstrong \& Seddon, 2008; Converse et al., 2013; Runge, 2013). This trial has informed an adaptive management framework for future reintroductions of warru and poses new hypotheses that can be tested in future releases.

The loss of individuals during the establishment phase is a common feature of reintroduction projects, referred to as the cost of release (Tavecchia et al., 2009; Hamilton et al., 2010). These losses can include mortalities as a result of translocation stress (Armstrong et al., 2007; Teixeira et al., 2007; Dickens et al., 2010) or can result from intraspecific competition with individuals from previous releases (Kleiman, 1989; Bertolero et al., 2007), predation and predator naïveté of released individuals (Moseby et al., 2011) or dispersal from the release site (Tweed et al., 2003; Le Gouar et al., 2008). The cost of release for this reintroduction was $38 \%$; we could not confirm the causes for any of these losses because inexperienced radio trackers failed to recognize mortality signals in time to retrieve bodies for post-mortem, highlighting the need for better training and supervision in future reintroduction attempts. However, we are confident that the deaths were as a result of the translocation itself as no pre-existing conditions were recorded in health checks prior to release. Deaths during reintroductions of captive-bred brush-tailed rock-wallabies to unfenced sites were mostly attributed to predation, although some were caused by disease, accidents, injuries and trapping incidents (Soderquist, 2011; Weeks, 2012). As introduced predators and competitors were excluded in this study and no incursions occurred, the deaths probably resulted from translocation stress or starvation, although we cannot rule out predation by native predators (wedge-tailed eagles Aquila audax or perentie Varanus giganteus), or accidents or illness.

Interactions with warru from previous releases may have contributed to the increased mortality of individuals supplemented in the second and third releases, although the sample size is limited. Males were housed separately in captivity and although females were housed in groups of two or three, these were not necessarily familiar groups prior to release. For some individuals, release into the exclosure was their first encounter with conspecifics. The introduction of naive individuals to established groups can disrupt social patterns and increase mortality (Kleiman, 1989); for example, survival of Hermann's tortoises Testudo hermanni hermanni was significantly lower in a second release, and this was attributed to the presence of tortoises from the first release (Bertolero et al., 2007). Brush-tailed rock-wallabies have a strong social structure, with related females living in close proximity to each other along cliff edges (Hazlitt et al., 2004), but this has not been examined for warru. Further supplementation of captive warru to the exclosure should be conducted and monitored to determine the effectiveness of supplementation as a strategy to increase population size within the exclosure, particularly with increasing population density. Adaptive management for future releases should include regular downloading of camera trap photographs before the first post-release trapping event to examine potential deterioration in the body condition of individuals, which could be used to trigger intervention.

All of the losses occurred within the first 10 weeks postreintroduction. It will be important to determine whether the cost of release decreases when future releases use individuals that have been born and raised within the exclosure rather than captive-bred individuals. Our results suggest that the first 3 months post-release is a critical period, when the intensity of monitoring should be highest to assess the likelihood of establishment and implement adaptive management. This will need to be followed by a comprehensive monitoring schedule to determine the medium- to long-term success of the reintroduction. Successful establishment and persistence has been recorded in reintroductions of captive-bred yellow-footed rock-wallabies into predator controlled areas, with a $20.8 \%$ cost of release in the first 21 days (Lapidge, 2001). Releases of captive-bred brush-tailed rock-wallabies into predator controlled areas in New South Wales have had higher release costs, with $57 \%$ of founders lost within 2 months of release and only $27 \%$ surviving 20 months after release (Soderquist, 2011). If losses in future reintroductions of warru exceed the level recorded here then management intervention will be required. The level of post-release loss recorded suggests that future releases should attempt to assess whether alternative translocation tactics (Batson et al., 2015) can reduce the cost of release; for example, larger group sizes may be required to ensure that enough individuals remain to establish a population. However, it will be important to conduct these releases in a staged manner to ensure that the causes of loss at new sites can be determined before large numbers of source animals are released.

Wild environments pose many survival challenges and pressures for newly released captive-bred individuals (Kleiman et al., 1994; Teixeira et al., 2007), the most immediate being that they must locate appropriate food resources within their new habitat (Mathews et al., 2005). Although biochemistry parameters can be influenced by a number of non-dietary variables, including reproduction, weather and age (Stirrat, 2003), they may also be used cautiously to assess nutrition (Robert \& Schwanz, 2013). Our blood biochemistry results were within wild reference ranges (Ruykys et al., 2012), indicating that warru maintained nutritional health post-release. Plasma albumin levels were indicative of adequate protein intake (Schultz et al., 2011) and although these decreased postrelease this probably reflects the higher protein concentration of pellets consumed in captivity (Lapidge, 2001). Ascorbic acid (vitamin C) and alpha-tocopherol (vitamin E) levels, which are presumed to be biosynthesized by rock-wallabies (Schultz et al., 2011), were maintained post-release, as were levels of FRAP, which is absorbed from vegetation and 
contributes to the antioxidant capacity of plasma (Ruykys et al., 2012). The cholinesterase levels observed in post-release warru were not indicative of infection or liver malfunction (Schultz et al., 2011). As urea levels typically increase during periods of dehydration or starvation (Lapidge, 2001; Ruykys et al., 2012), the significant decrease in urea concentration observed post-release indicates that reintroduced warru had adequate water intake and good nutrition (Stirrat, 2003). Water was provided quarterly during the study period and may have assisted adaptation to naturally fluctuating availability of water. We recommend providing supplementary water in future releases within an experimental framework to examine whether provision increases the establishment probability of released individuals and/or the presence of predators (potentially a negative effect) at supplemented sites in comparison to control sites.

Effective transition of captive-bred animals to a wild diet has been reported for the yellow-footed rock-wallaby, whose diet reflected a wild diet 2-4 months post-release (Lapidge, 2000). The body mass and nutritional profiles recorded here support similar timeframes of dietary adaption for captive warru. Although dietary composition post-release was not assessed directly, fresh scats collected within the first 2 weeks of release contained a high proportion of fig seeds, a preferred food plant of wild warru (Geelen, 1999). The fact that all of the mortalities recorded in this reintroduction occurred within 10 weeks of release could be indicative of a failure of those individuals to adapt to a wild diet, given the adaptation period reported for the yellow-footed rockwallaby. Investigating the role of starvation in mortalities would require faster retrieval of carcasses in future releases so that conclusive post-mortems could be conducted. The biochemistry results for surviving warru suggest that the current release site provided a nutritionally and structurally adequate environment, supporting the methods used to select the site (Ward et al., 2010), and we recommend that these same criteria are used for the selection of future release sites.

The adaptation of captive-bred warru to their new environment was also demonstrated by almost immediate conception in some of the females and high female reproductive rates throughout the study. The birth rates and frequencies recorded are similar to those observed in wild warru populations, where female breeding rates are $75-96 \%$, with births occurring throughout the year (Ward et al., 2011a). Our findings confirmed that $91 \%$ of pouch young survived to permanent pouch exit. The body condition of females has been found to influence the reproductive success of brush-tailed rockwallabies and survival of their pouch young (Wynd et al., 2006). The permanent pouch exit rates observed for warru provide further evidence for the successful adaptation of captive females to the wild environment, facilitating the maintenance of good condition post-release.

The reproductive rates recorded indicate that in future unfenced releases, female fecundity will offer the potential for rapid population growth post-release. However, only $52 \%$ of surviving pouch young were successfully recruited to the population. This rate is similar to the estimated juvenile survival rate for wild warru colonies ( $49 \%)$, which is believed to be limiting population growth (Ward et al., 2011a). The period following permanent pouch exit is when juvenile macropods are most vulnerable to mortality, often as a result of predation (Banks et al., 200o). In the wild the majority of predation pressure on warru is presumed to come from foxes, cats and wild dogs. Native predators such as wedge-tailed eagles and perentie are likely to be occasional predators of warru but are thought to have minimal impact on population growth (Read \& Ward, 2011a). Although foxes, cats and dogs were absent, we estimated there were three perentie inside the exclosure. As their diet is known to consist of small to medium sized mammals (James et al., 1992) and prey species such as rabbits were removed from the exclosure, it is possible that perentie could pose a threat to recruitment of young warru. Removal of perentie and subsequent monitoring of juvenile recruitment could test this hypothesis.

Alternative explanations for the modest recruitment rate observed within the exclosure are that juvenile warru are more trap-shy and less likely to be detected during trapping and/or that they are dispersing from the release site. Unmarked independent juveniles were sometimes recorded by camera traps immediately following a trapping session. Rock-wallaby species are known to exhibit dominance hierarchies and defend home ranges, with young males dispersing from natal colonies (Eldridge et al., 2001). Retaining the same trap positions each session may thus reduce the likelihood of detecting new individuals. To resolve this question we suggest increasing the trapping area when conducting cage trapping. It would also be useful to develop a lighter collar or tail transmitter design that could be attached to smaller individuals (1-2 kg) so that their initial survival within the population and possible dispersal could be determined.

An inherent lesson from this trial reintroduction has been the beneficial role of multiple monitoring methods in understanding post-release population dynamics. We found that uniquely marking individuals and placing camera traps at water points was a useful tool to supplement radio-tracking and cage trapping data. In addition to survival data the camera traps provided information on body condition and the presence of young-at-foot with females, information that would otherwise have been unavailable. We therefore recommend their use in future reintroductions.

This study provides an example of the role of intensive monitoring of trial reintroductions in providing critical data on reintroduction biology to help inform future reintroduction decisions and implement adaptive management. In the case of warru the hypotheses developed can now be used to guide adaptive management of future 
releases, with the aim of improving reintroduction outcomes.

\section{Acknowledgements}

Approvals to conduct the project were granted by the Anangu Pitjantjatjara Yankunytjatjara Executive Board, South Australia Department of Environment and Natural Resources Wildlife Ethics Committee (15/2007) and University of Adelaide Animal Ethics Committee (S-2011-9). Funding for the study was provided by the Warru Recovery Team, Norman Wettenhall Foundation, Margaret Middleton Fund, Sir Mark Mitchell Research Foundation, Nature Foundation SA (Edwards Majory Scholarship) and Adelaide Off Road. Fieldwork was conducted by various members of the Warru Recovery Team. We thank Anangu tjuta for supporting the project, B. Rich for biochemical analyses, and M. Eldridge for comments.

\section{References}

Armstrong, D.P., Castro, I. \& Griffiths, R. (2007) Using adaptive management to determine requirements of re-introduced populations: the case of the New Zealand hihi. Journal of Applied Ecology, 44, 953-962.

Armstrong, D.P. \& Seddon, P.J. (2008) Directions in reintroduction biology. Trends in Ecology \& Evolution, 23, 20-25.

BAAYEN, R.H. (2011) languageR: data sets and functions with Analyzing Linguistic Data: A Practical Introduction to Statistics using $R$, Cambridge University Press, Cambridge, UK.

BaAyen, R.H., Davidson, D.J. \& Bates, D.M. (2008) Mixed-effects modeling with crossed random effects for subjects and items. Journal of Memory and Language, 59, 390-412.

Banks, P.B., Newsome, A.E. \& Dickman, C.R. (200o) Predation by red foxes limits recruitment in populations of eastern grey kangaroos. Austral Ecology, 25, 283-291.

Bates, D., Maechler, M. \& Bolker, B. (2013) lme4: linear mixed-effects models using $\mathrm{S}_{4}$ classes. $R$ V. o.999999-2.

Batson, W.G., Gordon, I.J., Fletcher, D.B. \& Manning, A.D. (2015) REVIEW: Translocation tactics: a framework to support the IUCN Guidelines for wildlife translocations and improve the quality of applied methods. Journal of Applied Ecology, 52, 1598-1607.

Bertolero, A., Oro, D. \& Besnard, A. (2007) Assessing the efficacy of reintroduction programmes by modelling adult survival: the example of Hermann's tortoise. Animal Conservation, 10, 360-368.

Clayton, J.A., Pavey, C.R., Vernes, K. \& Tighe, M. (2014) Review and analysis of Australian macropod translocations 1969-2006. Mammal Review, 44, 109-123.

Converse, S.J., Moore, C.T., Folk, M.J. \& Runge, M.C. (2013) A matter of tradeoffs: reintroduction as a multiple objective decision. The Journal of Wildlife Management, 77, 1145-1156.

Delaney, R. \& De'Ath, G. (1990) Age estimation and growth rates of captive and wild pouch young of Petrogale assimilis. Wildlife Research, 17, 491-499.

Dickens, M.J., Delehanty, D.J. \& Michael Romero, L. (2010) Stress: an inevitable component of animal translocation. Biological Conservation, 143, 1329-1341.

Eldridge, M.D.B., Kinnear, J.E. \& Onus, M.L. (2001) Source population of dispersing rock-wallabies (Petrogale lateralis) identified by assignment tests on multilocus genotypic data. Molecular Ecology, 10, 2867-2876.

GeELEN, L. (1999) A preliminary study of the black-footed rock-wallaby (Petrogale lateralis MacDonnell Ranges race) in the Anangu Pitjantjatjara Lands, South Australia. BSc thesis. University of Adelaide, Adelaide, Australia.

Hamilton, L.P., Kelly, P.A., Williams, D.F., Kelt, D.A. \& Wittmer, H.U. (2010) Factors associated with survival of reintroduced riparian brush rabbits in California. Biological Conservation, 143, 999-1007.

Hazlitt, S.L., Eldridge, M.D.B. \& Goldizen, A.W. (2004) Fine-scale spatial genetic correlation analyses reveal strong female philopatry within a brush-tailed rock-wallaby colony in southeast Queensland. Molecular Ecology, 13, 3621-3632.

Hothorn, T., Bretz, F. \& Westfall, P. (2008) Simultaneous inference in general parametric models. Biometrical Journal, 50, 346-363.

IUCN (2013) Guidelines for Reintroductions and Other Conservation Translocations. Version 1.o. IUCN Species Survival Commission, Gland, Switzerland.

James, C.D., Losos, J.B. \& KING, D.R. (1992) Reproductive biology and diets of goannas (Reptilia: Varanidae) from Australia. Journal of Herpetology, 26, 128-136.

Kaplan, E.L. \& Meier, P. (1958) Nonparametric estimation from incomplete observations. Journal of the American Statistical Association, 53, 457-481.

Kemp, L.F., Norbury, G., Groenewegen, R. \& Comer, S. (2015) The roles of trials and experiments in fauna reintroduction programs. In Advances in Reintroduction Biology of Australian and New Zealand Fauna (eds D.P. Armstrong, M.W. Hayward, D. Moro \& P.J. Seddon), pp. 73-9o. CSIRO Publishing, Clayton South, Australia.

Kleiman, D.G. (1989) Reintroduction of captive mammals for conservation. BioScience, 39, 152-161.

Kleiman, D.G., Stanley Price, M.R. \& Beck, B.B. (1994) Criteria for reintroductions. In Creative Conservation: Interactive Management of Wild and Captive Animals (eds P.J.S. Olney, G.M. Mace \& A.T.C. Feistner), pp. 287-303. Chapman and Hall, London, UK.

LAPIDGE, S.J. (2000) Dietary adaptation of reintroduced yellow-footed rock-wallabies, Petrogale xanthopus xanthopus (Marsupialia: Macropodidae), in the northern Flinders Ranges, South Australia. Wildlife Research, 27, 195-201.

LAPIDGE, S.J. (2001) Reintroduction biology of yellow-footed rock-wallabies. $\mathrm{PhD}$ thesis. University of Sydney, Sydney, Australia.

Le Gouar, P., Robert, A., Choisy, J.P., Henriquet, S., Lecuyer, P., Tessier, C. \& Sarrazin, F. (2008) Roles of survival and dispersal in reintroduction success of griffon vulture (Gyps fulvus). Ecological Applications, 18, 859-872.

Mathews, F., Orros, M., Mclaren, G., Gelling, M. \& Foster, R. (2005) Keeping fit on the ark: assessing the suitability of captive-bred animals for release. Biological Conservation, 121, 569-577.

Moseby, K.E. \& Read, J.L. (2006) The efficacy of feral cat, fox and rabbit exclusion fence designs for threatened species protection. Biological Conservation, 127, 429-437.

Moseby, K.E., Read, J.L., Paton, D.C., Copley, P., Hill, B.M. \& CRISP, H.A. (2011) Predation determines the outcome of 10 reintroduction attempts in arid South Australia. Biological Conservation, 144, 2863-2872.

Moseby, K.E., Hill, B.M. \& Lavery, T.H. (2014) Tailoring release protocols to individual species and sites: one size does not fit all. PLoS ONE, 9(6), e99753.

Munic, J., Аввотt, E. \& Ward, M.J. (2012) The warru (Petrogale lateralis MacDonnell Ranges Race) reintroduction project on the 
Anangu Pitjantjatjara Yankunytjatjara Lands, South Australia. Ecological Management \& Restoration, 13, 89-92.

PeARson, D.J. (2012) Recovery Plan for Five Species of Rock Wallabies: Black-Footed Rock Wallaby (Petrogale lateralis), Rothschild Rock Wallaby (Petrogale rothschildi), Short-Eared Rock Wallaby (Petrogale brachyotis), Monjon (Petrogale burbidgei) and Nabarlek (Petrogale concinna) 2012-2022. Department of Environment and Conservation, Perth, Australia.

Pollock, K.H., Winterstein, S.R., Bunck, C.M. \& Curtis, P.D. (1989) Survival analysis in telemetry studies: the staggered entry design. The Journal of Wildlife Management, 53, 7-15.

R Development Core Team (2013) R: A Language and Environment for Statistical Computing. R Foundation for Statistical Computing, Vienna, Austria.

READ, J. \& WARD, M.J. (2011a) Warru Recovery Plan: Recovery of Petrogale lateralis MacDonnell Ranges Race in South Australia, 2010-2020. Department of Environment and Natural Resources, Adelaide, Australia.

READ, J.L. \& WARD, M.J. (2011b) Bringing back warru: initiation and implementation of the South Australian Warru Recovery Plan. Australian Mammalogy, 33, 214-220.

Robert, K.A. \& SchwanZ, L.E. (2013) Monitoring the health status of free-ranging tammar wallabies using hematology, serum biochemistry, and parasite loads. The Journal of Wildlife Management, 77, 1232-1243.

Runge, M.C. (2013) Active adaptive management for reintroduction of an animal population. The Journal of Wildlife Management, 77, 11351144 .

RUYKYs, L. (2011) Ecology of warru (Petrogale lateralis MacDonnell Ranges race) in the Anangu Pitjantjatjara Yankunytjatjara Lands, South Australia. PhD thesis. University of Adelaide, Adelaide, Australia.

Ruykys, L., Rich, B. \& McCarthy, P. (2012) Haematology and biochemistry of warru (Petrogale lateralis MacDonnell Ranges race) in captivity and the wild. Australian Veterinary Journal, 90, 331-340.

Schultz, D.J., Rich, B.G., Rohrig, W., McCarthy, P.J., Mathews, B., Schultz, T.J. et al. (2011) Investigations into the health of brush-tailed rock-wallabies (Petrogale penicillata) before and after reintroduction. Australian Mammalogy, 33, 235-244.

Sheean, V.A., Manning, A.D. \& Lindenmayer, D.B. (2012) An assessment of scientific approaches towards species relocations in Australia. Austral Ecology, 37, 204-215.

Short, J. (2009) The Characteristics and Success of Verterbrate Translocations within Australia. Unpublished report. Australian Government Department of Agriculture, Fisheries and Forestry, Canberra, Australia.

Soderquist, T. (2011) What we don't know and haven't learned about cost-benefit prioritisation of rock-wallaby management. Australian Mammalogy, 33, 202-213.

StirRat, S.C. (2003) Body condition and blood chemistry of agile wallabies (Macropus agilis) in the wet-dry tropics. Wildlife Research, 30, 59-67.

Taggart, D.A., Schultz, D.J., Fletcher, T.P., Friend, J.A., Smith, I.G., Breed, W.G. \& Temple-Smith, P.D. (2010) Cross-fostering and short-term pouch young isolation in macropodoid marsupials: implications for conservation and species management. In Macropods: The Biology of Kangaroos, Wallabies, and
Rat-kangaroos (eds G. Coulson \& M.D.B. Eldridge), pp. 263-278. CSIRO Publishing, Collingwood, Australia.

Tavecchia, G., Viedma, C., Martínez-Abraín, A., Bartolomé, M.-A., Gómez, J.A. \& Oro, D. (2009) Maximizing re-introduction success: assessing the immediate cost of release in a threatened waterfowl. Biological Conservation, 142, 3005-3012.

Teixeira, C.P., de Azevedo, C.S., Mendl, M., Cipreste, C.F. \& YounG, R.J. (2007) Revisiting translocation and reintroduction programmes: the importance of considering stress. Animal Behaviour, 73, 1-13.

Tweed, E.J., Foster, J.T., Woodworth, B.L., Oesterle, P., Kuehler, C., Lieberman, A.A. et al. (2003) Survival, dispersal, and home-range establishment of reintroduced captive-bred puaiohi, Myadestes palmeri. Biological Conservation, 111, 1-9.

Vogelnest, L. \& Woods, R. (2008) Medicine of Australian Mammals. CSIRO Publishing, Melbourne, Australia.

Ward, M.J., Read, J., Partridge, T., Taggart, D.A. \& Dent, A. (2010) Warru Pintji (fence) Site Selection. A Report to the Warru Recovery Team. Unpublished report. Department for Environment and Heritage, Adelaide, Australia.

Ward, M.J., Ruykys, L., van Weenen, J., de Little, S.C., Dent, A., Clarke, A. \& Partridge, T. (2011a) Status of warru (Petrogale lateralis MacDonnell Ranges race) in the Anangu Pitjantjatjara Yankunytjatjara Lands of South Australia. 2. Population dynamics. Australian Mammalogy, 33, 142-151.

Ward, M.J., Urban, R., Read, J.L., Dent, A., Partridge, T., Clarke, A. \& van Weenen, J. (2011b) Status of warru (Petrogale lateralis MacDonnell Ranges race) in the Anangu Pitjantjatjara Yankunytjatjara Lands of South Australia. 1. Distribution and decline. Australian Mammalogy, 33, 135-141.

WeEKs, A. (2012) Review of the Grampians Brush-tailed Rock-wallaby Reintroduction Program prepared for Department of Sustainability and Environment, Victoria and the Victorian Brush-tailed Rock-wallaby Recovery Team. Cesar, Parkville, Australia.

Woinarski, J., Burbidge, A. \& Harrison, P. (2014) The Action Plan for Australian Mammals 2012. CSIRO Publishing, Clayton, Australia.

Wynd, N.M., SigG, D.P., Pople, A.R., Hazlit t, S. \& Goldizen, A.W. (2006) Factors affecting female reproductive success and the survival of pouch young in the threatened brush-tailed rock-wallaby, Petrogale penicillata. Australian Journal of Zoology, 54, 61-70.

\section{Biographical sketches}

REBECCA WEST is an ecologist interested in reintroduction biology. She completed this work as part of her PhD research. JoHN READ is an ecologist with a particular research interest in adaptive management of populations of threatened species, especially the control of feral predators. MATTHEW WARD is a natural resources manager for the Alinytjara Wilurara Natural Resources Management Region. WENDY FOSTER is interested in integral ecology and the impact of people's behaviours, thoughts and emotions on their interactions with other individuals and species. DAVID TAGGART is an ecologist specializing in assisted breeding of marsupials for conservation, and wildlife health and disease in threatened species management. 